\title{
PENILAIAN SIKAP BERBASIS KURIKULUM 2013 DI SEKOLAH MENENGAH PERTAMA
}

\author{
Amalia Nurjannah \\ Sekolah Tinggi Ilmu Tarbiyah Raudhatul Ulum Sakatiga \\ Email: amalianurjannah@stit-ru.ac.id
}

\begin{abstract}
Abstrak
Penilaian merupakan istilah umum yang mencakup semua metode yang biasa digunakan untuk menilai kinerja peserta didik dalam pembelajaran. Kurikulum 2013 mengisyaratkan ada tiga ranah yang harus dinilai oleh guru pada peserta didiknya, yaitu pengetahuan, sikap, dan keterampilan. Kajian ini membahas teknik penilaian kompetensi sikap dalam pembelajaran. Penilaian sikap merupakan penilaian terhadap kecenderungan perilaku siswa sebagai hasil pendidikan, baik di dalam kelas maupun di luar kelas. Pada kenyataannya penilaian sesuai tuntutan Kurikulum 2013 belum terlaksana sebagaimana diharapkan. Permasalahan dilapangan menunjukkan guru belum terbiasa menggunakan berbagai teknik penilaian yang digunakan dalam Kurikulum 2013. Oleh karena itu, dalam kajian ini menjelaskan macam-macam penilaian kompetensi sikap beserta contoh-contoh penerapan dalam pembelajaran.
\end{abstract}

Kata Kunci: Penilaian, Sikap, Kurikulum

\section{Pendahuluan}

Pada tahun pelajaran 2013/2014 pemerintah mulai menerapkan kebijakan pemberlakuan Kurikulum 2013 yang diimplementasikan secara bertahap dan terbatas yang merupakan pembaharuan dan penyempurnaan Kurikulum 2006. Kurikulum 2013 ini menerapkan pembelajaran berbasis aktivitas, yang diharapkan akan menghasilkan insan Indonesia yang produktif, kreatif, inovatif, dan afektif melalui penguatan sikap, pengetahuan, dan keterampilan yang terintegrasi (Kemendikbud, 2015: 1). Hal ini berimplikasi pada pelaksanaan penilaian pencapaian kompetensi peserta didik.

Penilaian merupakan istilah umum yang mencakup semua metode yang biasa digunakan untuk menilai kinerja peserta didik dalam pembelajaran. Salah satu tahap penting dalam proses penilaian adalah pengumpulan informasi. Pengumpulan informasi ini akan dijadikan guru sebagai pengukuran dalam melakukan penilaian terhadap peserta didik. Dalam penilaian pendidikan, informasi yang dikumpulkan merupakan hasil belajar peserta didik baik yang sifatnya sikap, pengetahuan maupun keterampilan.

Salah satu prinsip penilaian yang tercantum dalam Peraturan Menteri Pendidikan Nasional RI No. 20 Tahun 2007 tentang Standar Penilaian Pendidikan adalah menyeluruh dan berkesinambungan. Menyeluruh berarti penilaian oleh guru mencakup semua aspek kompetensi (aspek kognitif, aspek psikomotor dan aspek 


\section{Penilaian Sikap Berbasis Kurikulum 2013 di Sekolah Menengah Pertama Amalia Nurjannah}

afektif) dengan menggunakan berbagai teknik penilaian yang sesuai. Berkesinambungan artinya penilaian dilakukan untuk memantau perkembangan kemampuan siswa.

Berdasarkan hasil penilaian, pendidik dapat mengambil keputusan secara tepat untuk menentukan langkah yang akan diambil selanjutnya. Hasil penilaian juga dapat memberikan motivasi kepada peserta didik untuk berprestasi lebih baik di kemudian hari.

Penilaian memiliki peran besar dalam menentukan kesuksesan pendidikan. Penilaian yang baik memberikan dampak pada proses pembelajaran (Popham, 2009: 13) dan menjadi rujukan untuk kebijakan selanjutnya (Mardapi, 2008: 5). Ketepatan pemilihan metode penilaian akan sangat berpengaruh terhadap objektivitas dan validitas hasil penilaian yang ujungnya adalah informasi objektif dan valid atas kualitas pendidikan. Sebaliknya kesalahan dalam memilih dan menerapkan metode penilaian juga berimbas pada informasi yang tidak valid mengenai hasil belajar dan pendidikan.

Berikut ini beberapa hal yang perlu diperhatikan dalam penilaian:

1. Penilaian yang dilakukan guru tidak hanya penilaian atas pembelajaran (assessment of learning), melainkan juga penilaian untuk pembelajaran (assessment for learning), dan penilaian sebagai pembelajaran (assessment as learning).

2. Penilaian diarahkan untuk mengukur pencapaian Kompetensi Dasar (KD) pada Kompetensi Inti (KI-1, KI-2, KI-3, KI-4).

3. Penilaian menggunakan acuan kriteria, yaitu penilaian yang membandingkan capaian siswa dengan kriteria kompetensi yang ditetapkan. Hasil penilaian seorang siswa, baik yang formatif maupun sumatif, tidak dibandingkan dengan hasil siswa lainnya namun dibandingkan dengan penguasaan kompetensi yang dipersyaratkan.

4. Penilaian dilakukan secara terencana dan berkelanjutan.

5. Hasil penilaian dianalisis untuk menentukan tindak lanjut, berupa program remedial bagi siswa yang pencapaian kompetensinya di bawah ketuntasan dan program pengayaan bagi siswa yang telah memenuhi ketuntasan (Kemendikbud, 2015: 1).

Pada kenyataannya penilaian sesuai tuntutan Kurikulum 2013 belum terlaksana sebagaimana diharapkan. Permasalahan dilapangan menunjukkan guru masih kesulitan dalam menyusun perencanaan penilaian, pelaksanaan penilaian, pengolahan hasil penilaian, serta pemanfaatan hasil penilaian. Hal ini disebabkan guru belum terbiasa menggunakan berbagai teknik penilaian yang digunakan dalam Kurikulum 2013.

Walaupun pemerintah telah mempersiapkan guru melalui berbagai pelatihan, namun masih banyak keluhan yang muncul di lapangan berkaitan dengan 
P-ISSN : 2541-3686

penilaian. Allen \& Friedman menyatakan bahwa yang paling kompleks dalam pembelajaran adalah integrasi pembelajaran berbagai domain yaitu kognitif, perilaku, dan perasaan (Allen, K. N., \& Friedman, 2010: 2). Menurut Retnawati salah satu aspek yang menjadi hambatan implementasi kurikulum 2013 adalah sistem penilaian yang rumit dan perlu waktu yang lama untuk menyusun laporanya (Rahmawati, 2015).

Berdasarkan latar belakang permasalahan tersebut maka jurnal ini menguraikan tentang penilaian kompetensi sikap berbasis Kurikulum 2013 di Sekolah Menengah Pertama.

\section{Pembahasan}

Penilaian kompetensi sikap dalam pembelajaran merupakan serangkaian kegiatan yang dirancang untuk mengukur nilai-nilai atau pandangan hidup yang diperoleh oleh peserta didik sebagai hasil suatu program pembelajaran. Penilaian sikap juga merupakan penilaian terhadap kecenderungan perilaku siswa sebagai hasil pendidikan, baik di dalam kelas maupun di luar kelas (Kemendikbud, 2015: 2). Kompetensi sikap terbagi menjadi dua, yaitu sikap spiritual dan sikap sosial.Pembagian ini diperlukan untuk menekankan pentingnya keseimbangan fungsi sebagai manusia seutuhnya yang mencakup aspek spiritual dan aspek sosial sebagaimana diamanatkan dalam tujuan pendidikan nasional.

1. Sikap Spiritual

Sikap spiritual terkait dengan pembentukan siswa menjadi orang beriman dan bertakwa kepada Tuhan Yang Maha Esa. Sikap spiritual mengacu pada kompetensi inti 1 (KI-1) pada kurikulum 2013 yang menyebutkan bahwa sikap spiritual merupakan sikap untuk selalu menerima, menghargai, menghayati danmengamalkan ajaran agama yang dianutnya.

\section{Sikap Sosial}

Sikap sosial terkait dengan pembentukan siswa yang berakhlak mulia, mandiri, demokratis dan bertanggung jawab. Sikap sosial merupakan kesadaran indvidu yang menentukan perbuatan yang nyata, yang berulang-ulang terhadap objek sosial. Objek sosial dalam sikap sosial adalah orang banyak dalam kelompok. Jadi yang menandai adanya sikap sosial adalah:

a) Subjek orang-orang dalam kelompoknya

b) Objeknya orang banyak (sekelompok orang) dalam kelompoknya

c) Dinyatakan atau dilakukan berulang-ulang

Dalam kurikulum 2013 sikap sosial mengacu pada kompetensi inti 2 (KI-2) yang menyebutkan bahwa sikap sosial terdiri sikap : jujur, disiplin, tanggung jawab, toleran, gotong royong, santun, dan percaya diri dalam berinteraksi dengan lingkungan sosial, seperti dengan keluarga, teman, guru dan tetangganya dalam jangkauan pergaulan dan keberadaannya (Widoyoko, 44-45).

Penilaian sikap dilakukan oleh guru mata pelajaran, guru bimbingan konseling (BK), dan wali kelas melalui observasi yang dicatat dalam jurnal berupa catatan 


\section{Penilaian Sikap Berbasis Kurikulum 2013 di Sekolah Menengah Pertama}

Amalia Nurjannah

anekdot dan catatan kejadian tertentu. Hal tersebut sesuai dengan pendapat Kunandar yakni guru melakukan penilaian kompetensi sikap melalui: (1) observasi, (2) penilaian diri, (3) penilaian teman sejawat (peer evaluation) oleh peserta didik, (4) jurnal (Kunandar, 2015: 119).

Skema penilaian sikap ini dapat dilihat pada gambar berikut.

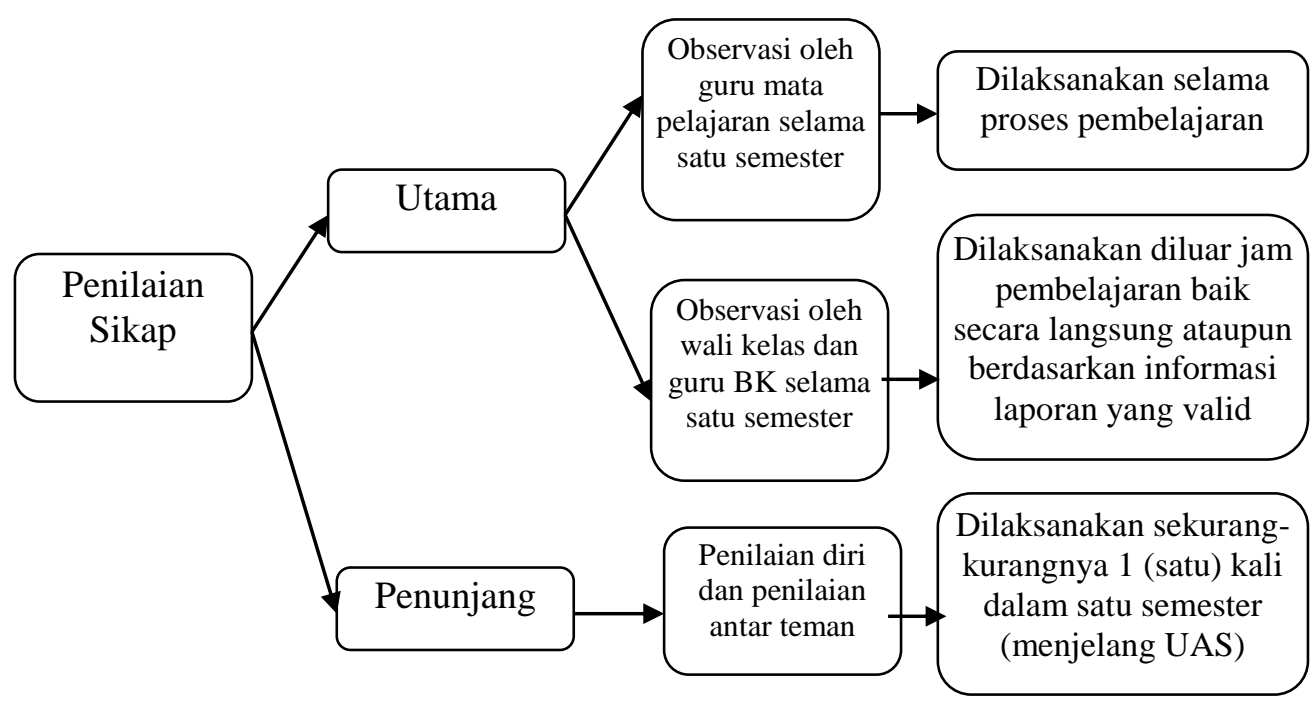

Gambar 1. Skema penilaian sikap

\section{Observasi}

Observasi adalah cara menghimpun bahan-bahan keterangan yang dilakukan dengan mengadakan pemngamatan dan pencatatan secara sistematis terhadap fenomena-fenomena yang sedang dijadikan sasaran pengamatan (Sudijono, 2015: 76). Kunandar menambahkan observasi merupakan teknik penilaian yang dilakukan secara berkesinambungan dengan menggunakan indera, baik secara langsung maupun tidak langsung dengan menggunakan pedoman atau lembar observasi yang berisi sejumlah indikator perilaku atau aspek yang diamati (Kunandar, 2015).

Tabel 1. Contoh penilaian sikap terhadap mata pelajaran PAI

$\begin{array}{lll}\text { Kelas/Semester } & : & \text { VII / Ganjil } \\ \text { TeknikPenilaian } & : & \text { Observasi }\end{array}$

\begin{tabular}{|l|l|l|l|l|l|l|}
\hline \multirow{2}{*}{ No. } & \multirow{2}{*}{ Nama Siswa } & \multicolumn{3}{|c|}{ Sikap Siswa } & \multirow{2}{*}{ Skor } \\
\cline { 3 - 5 } & & Terhadap & Terhadap & Terhadap & Dalam & \\
\hline
\end{tabular}


RAUDHAH Proud To Be Professionals gurnal Tarbiyakndlamiyak

Volume 4 Nomor 1 Edisi Juni 2019

P-ISSN : 2541-3686

\begin{tabular}{|c|c|c|c|c|c|c|c|}
\hline & & & Guru & $\begin{array}{c}\text { Aktivitas } \\
\text { KBM }\end{array}$ & $\begin{array}{c}\text { Sesama } \\
\text { Siswa }\end{array}$ & \begin{tabular}{c|} 
Kerja \\
Kelompok
\end{tabular} & \\
\hline 1 & \multicolumn{2}{|c|}{ Aan (contoh) } & A & B & A & $\mathrm{C}$ & 13 \\
\hline 2 & \multicolumn{2}{|l|}{..................... } & & & & & \\
\hline 3 & \multicolumn{2}{|l|}{$\ldots \ldots \ldots \ldots$} & & & & & \\
\hline 4 & \multicolumn{2}{|l|}{$\ldots \ldots \ldots \ldots$} & & & & & \\
\hline 5 & \multicolumn{2}{|l|}{ Dst. } & & & & & \\
\hline & & & & & & \\
\hline & & & & & & \\
\hline & & & & & & \\
\hline \multicolumn{3}{|c|}{ Jumlah Skor } & & & & & \\
\hline \multicolumn{3}{|c|}{ Keterangan } & \multicolumn{3}{|c|}{ Nilai } & \multicolumn{2}{|c|}{ Nilai Akhir } \\
\hline \multicolumn{2}{|c|}{$\begin{array}{l}\text { A. Sangat Baik } \\
\text { B. Baik } \\
\text { C. Cukup } \\
\text { K. Kurang }\end{array}$} & $\begin{array}{l}=\text { Skor } 4 \\
=\text { Skor } 3 \\
=\text { Skor } 2 \\
=\text { Skor } 1\end{array}$ & $\begin{array}{l}\text { Skor yan } \\
\text { Skormak }\end{array}$ & $\begin{array}{l}\text { diperoleh } \\
\text { nal }\end{array}$ & $0=----$ & & \\
\hline \multicolumn{8}{|c|}{ Catatan: } \\
\hline
\end{tabular}

Tanggal :

Guru Mata Pelajaran,

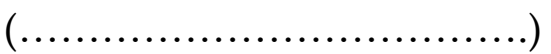

\section{Penilaian diri}

Penilaian diri adalah teknik cara meminta peserta didik untuk mengemukakan kelebihan dan kekurangan dirinya dalam konteks pencapaian kompetensi sikap, baik sikap spritual maupun sikap sosial terhadap lingkungannya (Kunandar, 2015: 134).

Penilaian diri dilakukan berdasarkan kriteria yang jelas dan objektif. Oleh karena itu, penilaian diri oleh peserta didik di kelas perlu dilakukan melalui Langkah-Langkah menurut Kunadar sebagai berikut: menentukan kompetensi atau aspek kemampuan yang akan dinilai, menentukan kriteria penilaian yang digunakan, merumuskan format penilaian, dapat berupa pedoman penskoran, 


\section{Penilaian Sikap Berbasis Kurikulum 2013 di Sekolah Menengah Pertama}

Amalia Nurjannah

daftar tanda cek, atau skala penilaian, meminta peserta didik untuk melakukan penilaian diri, guru mengkaji hasil penilaian untuk mendorong peserta didik supaya senantiasa melakukan penilaian diri secara cermat dan objektif, menyampaikan umpan balik kepada peserta didik berdasarkan hasilkajian terhadap penilaian diri, membuat kesimpulan terhadap hasil penilaian dengan menggunakan penilaian diri berkaitan dengan pencapaian kompetensi sikap spiritual dan sosial dari peserta didik, dan melakukan tindak lanjut dengan mengacu pada hasil penilaian melalui penilaian diri (Kunandar, 2015: 138).

Tabel 2. Contoh Penilaian Diri Sikap Peserta Didik terhadap Mata Pelajaran PAI

Nama Siswa

Kelas / Semester

VII / Satu

TeknikPenilaian

Penilaiandiri

Penilai

Diri sendiri

\begin{tabular}{|c|c|c|c|c|c|c|c|c|}
\hline \multirow[b]{2}{*}{ No. } & & \multirow{2}{*}{\multicolumn{2}{|c|}{ Pernyataan }} & \multicolumn{4}{|c|}{ Pilihan Jawaban } & \multirow{2}{*}{ Skor } \\
\hline & & & & $\begin{array}{l}\text { Sangat } \\
\text { Setuju }\end{array}$ & Setuju & $\begin{array}{l}\text { Ragu- } \\
\text { Ragu }\end{array}$ & $\begin{array}{l}\text { Tidak } \\
\text { Setuju }\end{array}$ & \\
\hline 1. & \multicolumn{3}{|c|}{$\begin{array}{l}\text { Meyakini bahwa tidak semua } \\
\text { ayat al-Quran merupakan } \\
\text { wahyu Allah Swt. }\end{array}$} & & & & & \\
\hline 2. & \multicolumn{3}{|c|}{$\begin{array}{l}\text { Meyakini bahwa semua ilmu } \\
\text { bersumber dari Allah Swt. }\end{array}$} & & & & & \\
\hline 3. & \multicolumn{3}{|c|}{$\begin{array}{l}\text { Meyakini bahwa menuntut } \\
\text { ilmu adalah perintah Allah } \\
\text { Swt. yang hukumnya wajib }\end{array}$} & & & & & \\
\hline 4. & \multicolumn{3}{|c|}{$\begin{array}{l}\text { Memahami kandungan al- } \\
\text { Quran dan mengamalkannya } \\
\text { tidak ada kaitannya dengan } \\
\text { keimanan seorang muslim. }\end{array}$} & & & & & \\
\hline 5. & \multicolumn{3}{|c|}{$\begin{array}{l}\text { Mampu membaca al-Quran } \\
\text { bukanlah suatu keharusan } \\
\text { bagi seorang muslim. }\end{array}$} & & & & & \\
\hline 6. & \multicolumn{3}{|c|}{$\begin{array}{l}\text { Meyakini bahwa Allah Swt. } \\
\text { memuliakan orang yang } \\
\text { berilmu }\end{array}$} & & & & & \\
\hline \multicolumn{4}{|c|}{ Jumlah Skor } & & & & & \\
\hline \multicolumn{4}{|c|}{ Keterangan } & \multicolumn{3}{|c|}{ Nilai } & \multicolumn{2}{|c|}{ Nilai Akhir } \\
\hline \multicolumn{2}{|c|}{$\begin{array}{l}\text { Pilihan: } \\
\text { Sangat Setuju } \\
\text { Setuju } \\
\text { Ragu-Ragu } \\
\text { Tidak Setuju } \\
\end{array}$} & $\begin{array}{l}\text { Positif } \\
=\text { Skor } 4 \\
=\text { Skor } 3 \\
=\text { Skor } 2 \\
=\text { Skor } 1\end{array}$ & $\begin{array}{l}\text { Negatif } \\
=\text { Skor } 1 \\
=\text { Skor } 2 \\
=\text { Skor } 3 \\
=\text { Skor } 4\end{array}$ & \multicolumn{3}{|c|}{$\begin{array}{l}\text { Skor yang } \\
\text { diperoleh }\end{array}$} & & \\
\hline \multicolumn{4}{|c|}{ Catatan: } & & & & & \\
\hline
\end{tabular}

Tanggal :

Siswa yang bersangkutan

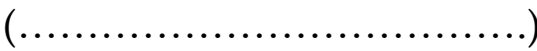


P-ISSN : 2541-3686

\section{Penilaian antar teman}

Penilaian antar peserta didik merupakan teknik penilaian yang dapat digunakan untuk mengukur tingkat pencapaian kompetensi sikap, baik sikap spiritual maupun sosial dengan cara meminta peserta didik untuk saling menilai satu sama lain (Kunandar, 2015: 144).

Penilaian antarpeserta didik oleh peserta didik dikelas perlu dilakukan melalui Langkah-Langkahsebagai berikut:menentukan kompetensi atau aspek kemampuan yang akan dinilai melalui penilaian antarpeserta didik, menentukan kriteria penilaian yang akan digunakan dalam penilaian antarpeserta didik, merumuskan format penilaian, dapat berupa pedoman penskoran, daftar tanda cek, atau skala penilaian, meminta peserta didik untuk melakukan penilaian antarpeserta didik secara objektif, guru mengkaji hasil penilaian untuk mendorong peserta didik supaya senantiasa melakukan penilaian antarpeserta didik secara cermat dan objektif, menyampaikan umpan balik kepada peserta didik berdasarkan hasil kajian terhadap penilaian antarpeserta didik, membuat kesimpulan terhadap hasil penilaian dengan menggunakan penilaian antarpeserta didik berkaitan dnegan pencapaian kompetensi sikap spiritualdan sosial dari peserta didik, dan melakukan tindak lanjut dengan mengacu pada hasil penilaian melalui penilaian antarpeserta didik (Kunandar, 2015: 148).

Tabel 3. Contoh Instrumen Penilaian AntarPeserta Didik

Nama Siswa yang dinilai :

Kelas/Semester

: VII / Ganjil

TeknikPenilaian

: Penilaian Antarteman .

\section{Petunjuk:}

a. Dibuat kelompok peserta didik dengananggotamasingmasing 5-10 orang.

b. Tiap-tiap anggota kelompokmenilaianggota lain dalam kelompoknya, termasuk menilai dirinya sendiri.

c. Membuatrekappenilaianuntuktiap-tiap pesertadidik dalam kelompok secara keseluruhan.

\begin{tabular}{|c|l|c|c|c|c|c|}
\hline \multirow{2}{*}{ No. } & \multicolumn{1}{|c|}{ Pernyataan } & \multicolumn{3}{|c|}{ Pilihan Jawaban } & \multirow{2}{*}{ Skor } \\
\cline { 3 - 5 } & Selalu & Sering & $\begin{array}{c}\text { Kadang- } \\
\text { kadang }\end{array}$ & $\begin{array}{c}\text { Tidak } \\
\text { Pernah }\end{array}$ & \\
\hline 1 & $\begin{array}{l}\text { Memiliki semangat tinggi } \\
\text { dalam menuntut ilmu. }\end{array}$ & & & & & \\
\hline 2 & $\begin{array}{l}\text { Mengajarkan ilmu kepada } \\
\text { orang lain yang } \\
\text { membutuhkan. }\end{array}$ & & & & & \\
\hline
\end{tabular}


Penilaian Sikap Berbasis Kurikulum 2013 di Sekolah Menengah Pertama Amalia Nurjannah

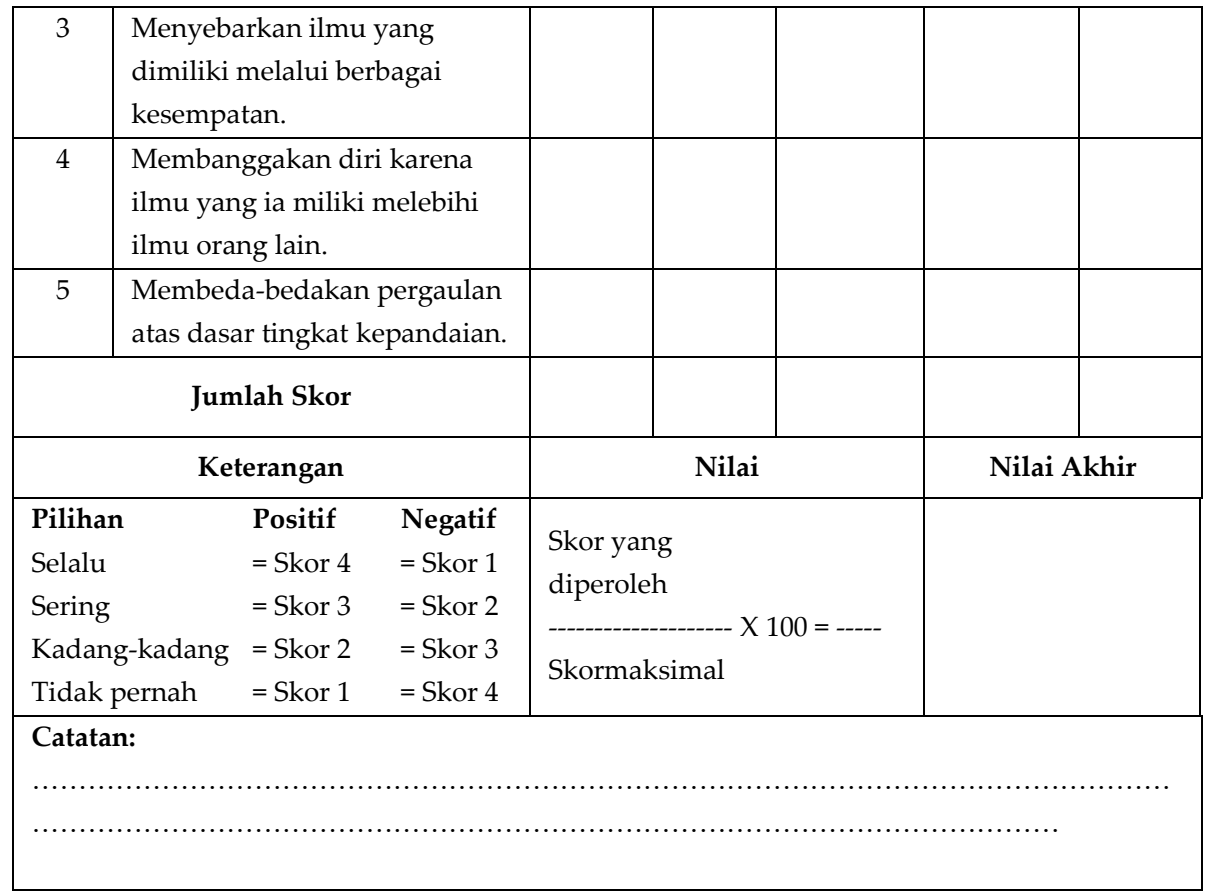

Tanggal :

Ketua kelompok,

\section{Jurnal}

Jurnal adalah catatan pendidik di dalam dan di luar kelas yang berisi informasi hasil pengamatan tentang kekuatan dan kelemahan peserta didik yang berkaitan dengan sikap atau perilaku (Kunandar, 2015: 151).

Penilaian jurnal ini dikatakan lebih efektif dikarenakan setiap pembelajaran guru selalu memberi penilaian kepada siswanya dengan cara mencatat dalam catatan yang dimiliki oleh pendidik atau guru kelas sendiri. Sehingga semua peserta didik dapat terlihat perubahan yang signifikan terhadap setiap pembelajaran di kelasnya dan guru dapat memberikan penanganan atas peserta didiknya.

Tabel 4. Contoh Buku Catatan Harian Peserta Didik

\section{BUKU CATATAN HARIAN \\ TENTANG SIKAP DAN PERILAKU PESERTA DIDIK}

Mata Pelajaran

Kelas

Tahun Pelajaran

Nama Guru

\begin{tabular}{|c|c|c|c|c|c|}
\hline No & $\begin{array}{c}\text { Hari, } \\
\text { Tanggal }\end{array}$ & $\begin{array}{c}\text { Nama } \\
\text { Siswa }\end{array}$ & $\begin{array}{c}\text { Kejadian/ } \\
\text { peristiwa }\end{array}$ & Tindakan & $\begin{array}{c}\text { Feed Back } \\
\text { Siswa }\end{array}$ \\
\hline
\end{tabular}


RAUDHAH Proud To Be Professionals Jurnal Tarbiyah)damiyah

Volume 4 Nomor 1 Edisi Juni 2019

P-ISSN : 2541-3686

\begin{tabular}{|c|c|c|c|c|c|}
\hline 1 & $\begin{array}{l}\text { Kamis, } 7 \\
\text { Maret } \\
2019\end{array}$ & $\begin{array}{l}\text { Aan } \\
\text { (Contoh) }\end{array}$ & $\begin{array}{l}\text { - Tidur } \\
\text { dikelas } \\
\text { - Tidak } \\
\text { membawa } \\
\text { buku paket }\end{array}$ & $\begin{array}{l}\text { Siswa diberi } \\
\text { teguran, } \\
\text { disuruh cuci } \\
\text { muka dan } \\
\text { diminta } \\
\text { meminjam di } \\
\text { kelas lain } \\
\end{array}$ & $\begin{array}{l}\text { Setelah diberi } \\
\text { nasehat dan } \\
\text { teguran siswa } \\
\text { merubah } \\
\text { sikapnya pada } \\
\text { pertemuan } \\
\text { selanjutnya. }\end{array}$ \\
\hline 2 & & & & & \\
\hline 3 & & & & & \\
\hline 4 & Dst & & & & \\
\hline
\end{tabular}

\section{Simpulan}

Teknik penilaian untuk menilai domain Sikap digunakan ada empat teknik, yaitu Observasi (langsung atau tidaklangsung), Penilaian Diri, Penilaian teman sejawat, dan Jurnal. Untuk mengatasi berbagai permasalahan guru dilapangan mengenai penilaian perlu membuat dan menyederhanakan pedoman penilaian pada Kurikulum 2013, melakukan sosialisasi dan pelatihan penilaian kompetensi sikap, serta membimbing guru melakukan kegiatan dalam pembuatan, pelaksanaan dan pengolahan, serta pemanfaatan dan tindak lanjut hasil penilaian. 


\section{Penilaian Sikap Berbasis Kurikulum 2013 di Sekolah Menengah Pertama}

Amalia Nurjannah

\section{DAFTAR PUSTAKA}

Allen, K. N., \& Friedman, B. D. (2010). Affective learning: A taxonomy for teaching social work values. Journal of Social Work Values and Ethics, 7(2).

Kemendikbud. (2015).Panduan Penilaian untuk SMA. Jakarta: Kemendikbud

Kunandar (2015). Penilaian Autentik(Penilaian Hasil Belajar Peserta Didik Berdasarkan Kurikulum 2013). Jakarta: PT Raja Grafindo

Mardapi, D. (2008). Teknik penyusunan instrumen tes dan nontes. Yogyakarta: Mitra Cendikia Press.

Popham, W. J. (2009). Instruction that up measures up. Virginia: ASCD.

Retnawati, H. (2015). Hambatan guru matematika sekolah menengah pertama dalam menerapkan kurikulum baru. (Cakrawala Pendidikan).

Sudijono, A. (2015). Pengantar Evaluasi Pendidikan. Jakarta: Rajawali Press 